\title{
IN VITRO MULTIPLICATION OF JABON (ANTHOCEPHALUS CADAMBA (ROXB)) ON VARIOUS CONCENTRATION OF BAP AND IAA
}

\author{
Asgar Taiyeb ${ }^{1}$ and Baharuddin ${ }^{2}$ \\ ${ }^{1}$ Lecturer at Department of Forestry, Faculty of Forestry, University of Tadulako \\ ${ }^{2)}$ Laboratory of Forestry Sciences, Faculty of Forestry, University of Tadulako
}

\begin{abstract}
One of problems in the Jabon propagation is the availability of seeds both quality and quantity. Tissue culture technology is one of the alternatives that can be used for the supply of Jabonseeds to produce organs of plants (buds, leaves, roots). The success of plant tissue culture techniques is determined by the condition of explants, a supportive environment and the addition of growth regulators are expected to provide a response to the cultured explants. This study aimed to know the effect of Benzyl Amino Purine (BAP) and Indole Acetic Acid (IAA) to in vitro multiplication of Jabon. This research conducted at the Laboratory of Forestry Sciences, Faculty of Forestry, University of Tadulako from March to May 2015. Using a completely randomized design with treatments: $0.1 \mathrm{mg} / 1$ $\mathrm{IAA}+1 \mathrm{mg} / 1 \mathrm{BAP}(\mathrm{JB} 1), 0.1 \mathrm{mg} / 1 \mathrm{IAA}+1.5 \mathrm{mg} / 1 \mathrm{BAP}(\mathrm{JB} 2), 0.1 \mathrm{mg} / 1 \mathrm{IAA}+2 \mathrm{mg} /$ $1 \mathrm{BAP}(\mathrm{JB} 3)$ and $0.1 \mathrm{mg} / 1 \mathrm{IAA}+2.5 \mathrm{mg} / 1 \mathrm{BAP}(\mathrm{JB} 4)$. Each treatment was repeated three times to obtain 12 experimental units. The results showed that the difference in response Jabon of treatment tested was the highest number of buds and leaves were in the media added $0.1 \mathrm{mg} / 1 \mathrm{IAA}+1.5 \mathrm{mg} / 1 \mathrm{BAP}$. Furthermore, the formation of callus obtained in media which added $0.1 \mathrm{mg} / 1 \mathrm{IAA}+1 \mathrm{mg} / 1 \mathrm{BAP}$.
\end{abstract}

Key words: BAP, IAA, in Vitro, Jabon.

\section{INTRODUCTION}

Jabon (Anthocephalus cadamba (Roxb) Miq) is a famous type of tropical tree from South Asia and Southeast Asia, including Indonesia (Krisnawati, Kallio and Kanninen, 2011). Jabon has the prospect in establishment of forest plantations. It is a fast growing species with high production. Along the demand increasing, necessary commodities have thefast growth with quality wood. Jabon tree (Anthocephalus $s p$ ), which is one good forestry commodities for a period of 5 years with the diameter of the timber has reached $30-40 \mathrm{~cm}$. Jabon can be harvested in two stages, namely the third year with the wood diameter of $20-25 \mathrm{~cm}$ with thinning. The second stage called the harvest which is usually in the fifth year (Mansur and Tuheteru, 2010).

Besides growing fast, Jabon also has various functions which can benefit the forest where planted, namely : 1). Jabon can speed up the vegetation of forest plantation. 2 ). Jabon can increase the productivity of crop land in the surrounding areas. 3). Jabon is potentially regulate the water system in the soil and 4). Preventing soil erosion. 5). Finally, important economic value can be utilized to generate a high price (www.toytrac.cheats-game.com, 2011).

Mansur and Tuheteru (2010) stated that the cultivation techniques ofJabon is easy to do, but cultivation on a large scale 
Indonesia is still relatively new commercial. Jabon timber needs will be continue to increase, while replanting is still lacking. Overcome these problems, it is necessary to replanting Jabon in large numbers. It must be supported by seed stocks which are superior in terms of both quality and quantity and also match the expected results.

In order to solvethe problems in the provision of Jabon seeds as one of the alternatives that can be done by using tissue culture techniques. Some of the critical success factors of tissue culture are the type and concentration of growth regulators given the basic medium.

Types of growth regulators are often used from the class of cytokinin and auxin are Benzyl Amino Purine (BAP) and Indole Acetic Acid (IAA). The addition of different growth regulators have different effects on each plant. Each plant requires optimum concentration for any growth regulators to support their growth. Experiments have been done before with the addition of a combination of auxin and cytokinin BAP IAA show results is not optimal because it has not produced a perfect plantlets and plant growth is not optimal, although it had obtained sufficient shoot multiplication. An assumed, the combination of concentration is not optimal to support good growth.

Based on the background above, the research carried out in vitro propagation Jabon by trying to do a combination of various concentration of Benzyl Amino Purine (BAP) and Indole Acetic Acid (IAA) to the multiplication of Jabon.

This research aimed to determine the best combination of concentration Benzyl Amino Purine (BAP) and Indole Acetic Acid (IAA) for multiplication of Jabon on in vitro. The usefulness of this research is expected to help in propagation, and as information for other researchers, especially research about in vitro of Jabon.

\section{MATERIALS AND METHODS}

This research conducted at the Laboratory of Forestry Sciences Faculty of
Forestry, University of Tadulako of Palu. This study started from March to May 2015.

The material used were sterile Jabon, 70\% alcohol, detergents, Dithane, jelly, sucrose, filter paper, tissue paper, paper labels, chlorox, spritus, distilled sterile, growth regulators BAP (Benzyl Amino Purine) and IAA (Indole Acetic Acid).

The tools used are Laminar Air Flow Cabinet (LAFC), autoclave, hot plate, analytical balance, magnetic stirrer, measuring cups, funnels, hand sprayer, pipettes, scalpel, tweezers, Bunsen burner, aluminum foil, clippers, Beakers, petri dishes, refrigerator, electric oven, culture bottles, rubber bands and caps.

This research use completely randomized design (CRD), which consisted of four treatments, namely:

$\mathrm{JB}_{1}=1 \mathrm{mg} / \mathrm{l} \mathrm{BAP}+0.1 \mathrm{mg} / \mathrm{l} \mathrm{IAA}$

$\mathrm{JB}_{2}=1.5 \mathrm{mg} / \mathrm{l} \mathrm{BAP}+0.1 \mathrm{mg} / \mathrm{l} \mathrm{IAA}$

$\mathrm{JB}_{3}=2 \mathrm{mg} / \mathrm{l} \mathrm{BAP}+0.1 \mathrm{mg} / \mathrm{l} \mathrm{IAA}$

$\mathrm{JB}_{4}=2.5 \mathrm{mg} / \mathrm{l} \mathrm{BAP}+0.1 \mathrm{mg} / \mathrm{l} \mathrm{IAA}$

Each experiment was repeated three times, thus there were 12 experimental units. The number of buds and leaves were obtained then in the analysis of variance and comparison test between treatments using the Statistical Product and Service Solution (SPSS) 16.0 software. If the analysis of variance shows significant or very significant, it will proceed with HSD test at 5\% level (Hanafiah, 2004).

\section{RESULTS AND DISCUSSIONS}

\section{Results}

The results of statistical analysis show that the number of buds of Jabon was not significant effect on the treatment. Mean of the number of buds can be seen in Table 1. Table 1 shows that the addition of $1.5 \mathrm{mg} / 1 \mathrm{BAP}+0.1 \mathrm{mg} / 1 \mathrm{IAA}$ (JB2) gave the highest number of buds (14.33).

The results of statistical analysis showed that the number of leaves of Jabonwere significant to the treatment. The number of leaves on various of treatments can be seen in Table 2. 
Table 1. Means of the number of buds of Jabon

\begin{tabular}{|c|c|c|c|c|c|}
\hline \multicolumn{2}{|c|}{ Treatment } & & \multicolumn{3}{|c|}{ Mean } \\
\hline & JB1 & & & & 8.67 \\
\hline & JB2 & & & & 14.33 \\
\hline & JB3 & & & & 11.33 \\
\hline & JB4 & & & & 10.00 \\
\hline Source & $\begin{array}{c}\text { Type III Sum of } \\
\text { Squares }\end{array}$ & df & Mean Square & $\mathrm{f}$ & Sig \\
\hline Coorected Model & $52,917^{\mathrm{a}}$ & 3 & 17.639 & 2.433 & 0.140 \\
\hline Intercept & 1474.083 & 1 & 1474.083 & 203.322 & 0.000 \\
\hline Treatment & 52.917 & 3 & 17.639 & 2.433 & 0.140 \\
\hline Error & 58.000 & 8 & 7.250 & & \\
\hline Total & 1585.000 & 12 & & & \\
\hline Corrected Total & 110.917 & 11 & & & \\
\hline
\end{tabular}

R Squared $=0.477$ (Adjusted R Squared $=0.281$

Table 2. Means of the number of leaves of Jabon

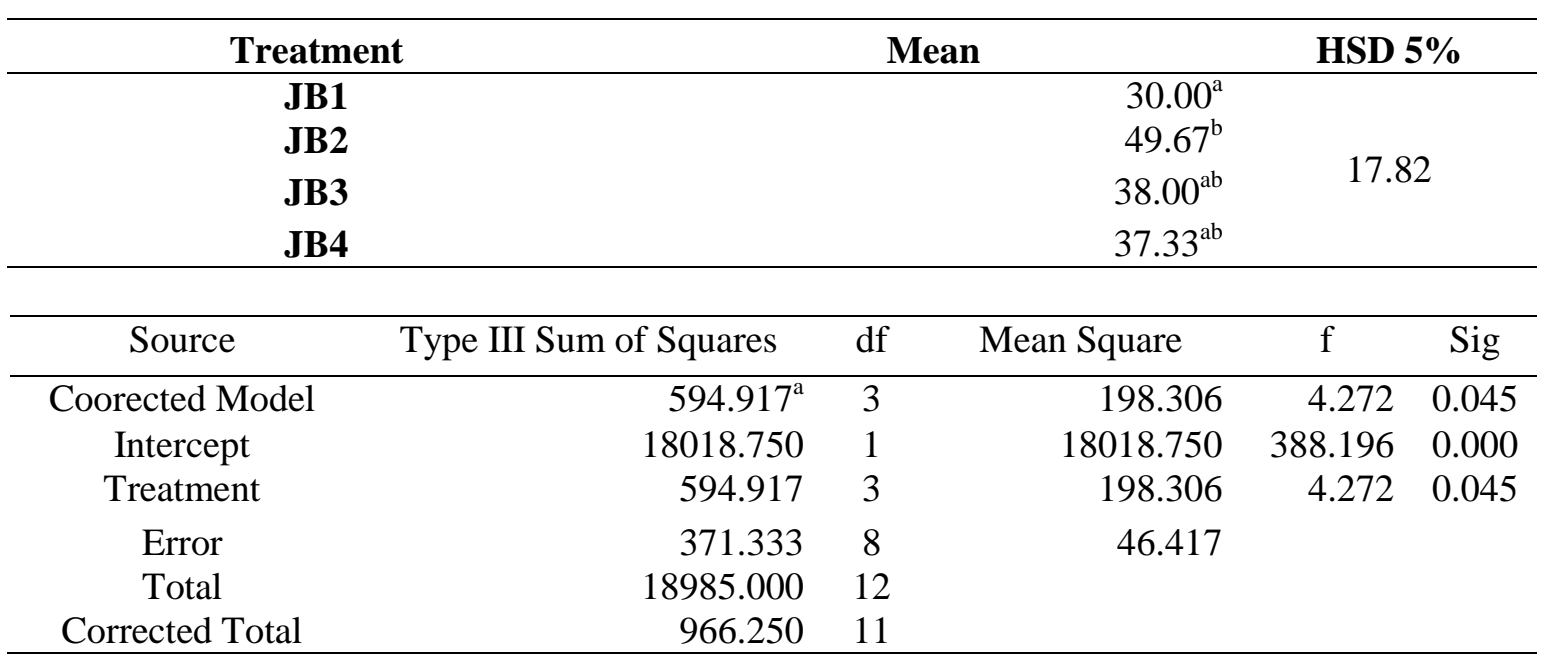

R Squared $=0.616($ Adjusted R Squared $=0.472)$

Remarks : Mean within a column and a row followed by the same letter did not differ significantly using HSD ( $p=0.05)$.

Table 3. The formation of callus of Jabon

\begin{tabular}{lccc}
\hline \multirow{2}{*}{ Treatment } & \multicolumn{2}{c}{ Replication } \\
\cline { 2 - 4 } & $\mathbf{1}$ & $\mathbf{2}$ & $\mathbf{3}$ \\
\hline JB1 & + & + & - \\
JB2 & - & - & - \\
JB3 & - & - & - \\
JB4 & - & - & - \\
\hline
\end{tabular}

Remarks : $+=$ Formed Callus

- $=$ No formed callus 


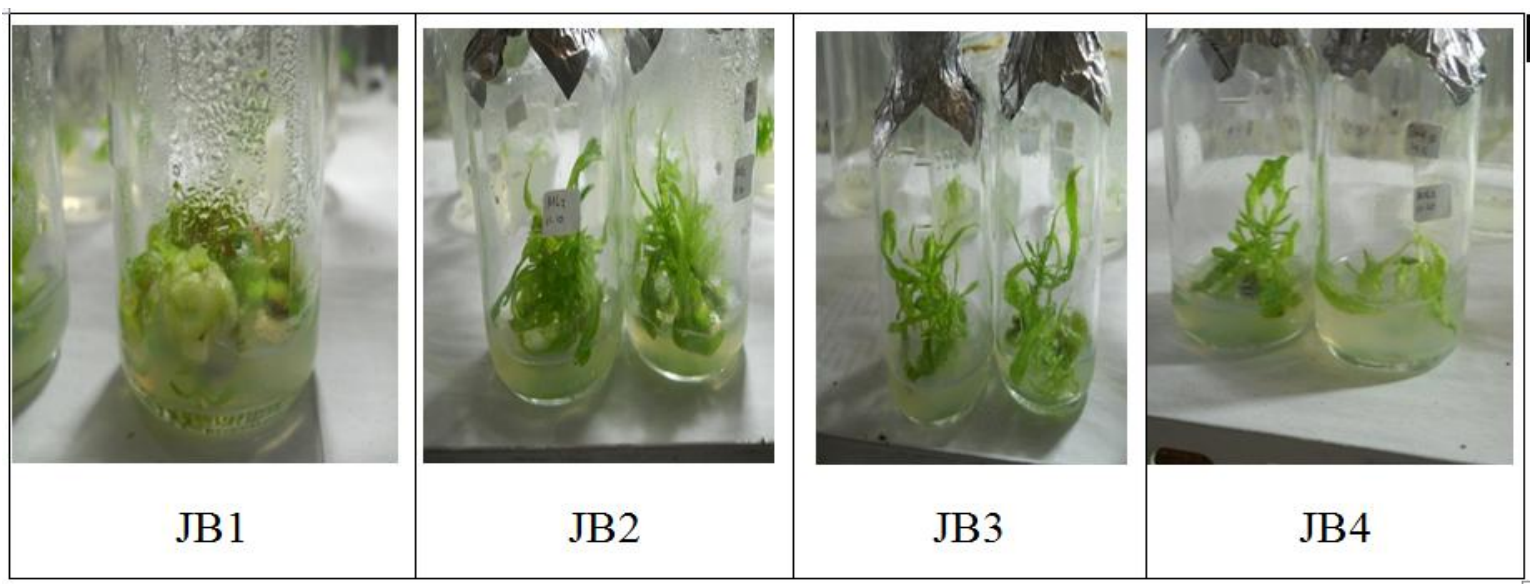

Figure 1. Result of In Vitro Multiplication of Jabon

Test results of HSD at the level of $5 \%$ was obtained number of leaves the highest one is the media which added 1.5 $\mathrm{mg} / 1 \mathrm{BAP}+0.1 \mathrm{mg} / \mathrm{IAA}(\mathrm{JB} 2)$ with the average value of 49.67 and did not differ in the media added $2 \mathrm{mg} / 1 \mathrm{BAP}+0.1 \mathrm{mg} / 1$ IAA (JB3), as well as in the media with the addition of $2.5 \mathrm{mg} / 1 \mathrm{BAP}+0.1 \mathrm{mg} / \mathrm{l} \mathrm{IAA}$ (JB4), but differ in the media $1 \mathrm{mg} / 1 \mathrm{BAP}$ $+0.1 \mathrm{mg} / 1$ IAA (JB1).

The formation of callus on various of treatments can be seen in Table 3 .

The results shows callus formed on the medium were added $1 \mathrm{mg} / 1 \mathrm{BAP}+0.1$ $\mathrm{mg} / \mathrm{I}$ IAA (JB1), except in three replications callus was not formed. While on JB2, JB3 and JB4 treatment there was no callus formed in all teste dreplications.

\section{Discussions}

The success of plant regeneration in tissue culture is determined by many factors. The effects of growing factor are classified into four main groups, namely genotype, components of the media including the growth regulators, growing environment and physiology of plant tissue is used as explants. According to Wattimena et al. (1992), these factors should be in a suitable state to obtain optimal growth and development for each type of plant. The results shows that the addition of IAA and various concentrations of BAP was significantlyaffecting the number of leaves but was not significantly affecting the number of buds.

The addition of plant growth regulators into tissue culture medium was intended tostimulate the formation of plant organs (shoots, leaves and roots). BAP Given (cytokines categoy) alone was often used for plant propagation, such as the research of Meyriani (2006) that the addition of $0.1 \mathrm{mg} / 1 \mathrm{BAP}$ gives good results on the number of leaves, the speed of buds formation and roots formation and the addition of $0.3 \mathrm{mg} / 1 \mathrm{BAP}$ provides the highest number of buds on organ ogenesis of cocoa. Jumat (2014), reported that the addition $1,0 \mathrm{Mg} / \mathrm{l}$ BAP gives good results on bud height, the number of buds and leaves of Red Jabon (Anthocephalus macrophyllus Roxb).

However, some types of plants also produce organs better when combined with a class of plant growth regulator auxin (IAA / NAA / IBA). Andriana (2001) reported that the addition of $3 \mathrm{ppm} \mathrm{BAP}+0.02 \mathrm{ppm}$ NAA gives the best results to speed the formation of buds, the number of buds, number of leaves and number of roots mostly in peanut. Wahyufi (2002) also reported that the concentration of $0.5 \mathrm{ppm}$ IBA +7 ppm BAP gives the best results to appear when the shoots, the number of buds and leaves of melon.

The results show that the IAA and various concentrations of BAP make a 
difference to the number of formed buds. The most number of buds by $1.5 \mathrm{mg} / 1$ BAP + $0.1 \mathrm{mg} / 1 \mathrm{IAA}(\mathrm{JB} 2)$ was 14.33. The lowest number of shoots had obtained on treatment with a concentration of $1 \mathrm{mg} / 1$ $\mathrm{BAP}+0.1 \mathrm{mg} / 1 \mathrm{IAA}$ (JB1), namely 8.67.

According to the results, the addition of $1.5 \mathrm{mg} / 1 \mathrm{BAP}+0.1 \mathrm{mg} / 1 \mathrm{IAA}$ was more effective in promoting and encouraging the formation of buds than the other treatments. The concentration of 1.5 $\mathrm{mg} / 1 \mathrm{BAP}+0.1 \mathrm{mg} / 1 \mathrm{IAA}$ added to media will go through the process of diffusion and absorption of the active. The absorption of growth regulators subsequently will lead to increased growth regulator substances (endogenous hormone) in the body of plants (Gunawan, 1988).

The results of the study i.e the number of leaves of Jabon (Table 2) shown on JB2 treatment $(1.5 \mathrm{mg} / 1 \mathrm{BAP}+0.1 \mathrm{mg}$ / 1 IAA) that also be obtained the highest number of leaves with mean of 49.67 , while the fewest of the number of leaves be obtained at JB1 treatment (1 mg / 1 BAP + $0.1 \mathrm{mg} / 1$ IAA) with the mean of 30.00 . Based on these results, that is clear that any type and concentration of growth regulators used in tissue culture either single or combination responded differently of each type of plant. JB2 treatment (1.5 mg / 1 BAP $+0.1 \mathrm{mg} / \mathrm{l}$ IAA) was suitable condition characterized by the most formation of buds and leaves of Jabon.

The observations of the root of Jabon at eight weeks after planting in the all experiments have not formed roots. Hopkins (1995), stated that the formation of roots at explant is strongly influenced by hormone content in the body of plant or added into media. This was explained by Marks and Simpson (2000) and Howard (1996) in Mahari (2011), the ability of planlet of roots is influenced by several factors such us genotype, maturity and physiological characteristics.

The observation of the presence or absence of callus formed only on JB1 treatment $(1 \mathrm{mg} / \mathrm{l} \mathrm{IAA}+0.1 \mathrm{mg} / \mathrm{l} \mathrm{BAP})$. Callus is a group of cells that occur from tissue cells early defend themselves continuously to form a tissue wound closure. According to Husen (2001), the growth of callus in tissue culture involves a complex relationship between the planting material used, the composition of the media, growth regulators and environmental conditions during the incubation period.

In principle, phase multiplication aimed to double propagules or plant material propagated like buds or embryos which stimulate the multiplication of shoots or leaves to encourage branching lateral buds or stimulate the formation of adventitious buds (Yusnita, 2004).

\section{REFERENCES}

Andriana, A., 2001. Regeneration of Kacang Tanah (Arachis hypogea) on Somatic Embryos.Bachelor Thesis (not published). Agriculture Faculty, Tadulako University.Palu.

Gunawan L.W, 1988. Tissue Culture Technique.PusatAntarUniversitas (PAU) Bioteknologi, InstitutPertanian Bogor, Bogor.

Hanafiah, K.A., 2004. Experimental Design.3rd Edition.PT. RajaGrafindoPersada. Jakarta.

Hopkins, W.G., 1995. Introduction to PlantPhysiologi.Jhon Wiley and Sons, Inc, New York.

Jumat, J. L. 2014. In VitroMultiplication ofSamama (Anthocephalusmacrophyllus (Roxb) Havil) With Apical and Axillary Buds.Seminar Nasional Basic Science VI F-MIPA Unpatti, Ambon. 
Krisnawati, H., Kallio, M., Kannien, M. 2011. Anthocepahalus cadamba Miq., Ecology, Silvikultureand Productivity. www.cifor.cgiar.org. Accessed 30 July 2014.

Meyriani, D., 2006. Organogenesis TanamanKakao (Theobroma cacao) on Various Consentration of Benzylamino Purine.Bachelor Thesis (not published). Agriculture Faculty.Tadulako University.Palu.

Mansur, I dan Tuheteru, F.D, 2010. Jabon Wood. Penebar Swadaya. Jakarta.

Maharia, D., 2011. In Vitro Initiation and Multiplication of Jabon (Anthocephaluscadambaon Various Concentration of Benzylaminopurine and Kinetin. Thesis (not published). Magister Program, Tadulako University.Palu.

Wattimena G.A., L.W. Gunawan, Nurhayati, A.M.E. Syamsudin, N.M.A. Weindi, dan A. (Roxb)) Ernawati, 1992. Plant Bioteknology $1^{\text {st }}$. Departemen Pendidikandan Kebudayaan DirektoratJenderalPendidikanTinggi.PusatAntarUniversitasBioteknologi, IPB Bogor.

Yusnita, 2004. Tissue Culture, How to Reproduce EfficientlyPlant.Agromedia Pustaka, Jakarta.

www.toytrac.cheats-game.com/Manfaat-Pohon-Jabon. Accessed 02 Desember 2013. 